\title{
Atypical manifestations in CAPS sydrome: not so unfrequent?
}

\author{
S Buján-Rivas ${ }^{1 *}$, M Basagaña-Torrentó ${ }^{2}$, C Modesto-Caballero ${ }^{1}$, Jl Aróstegui-Gorospe $^{3}$, M Vilardell-Tarrès ${ }^{1}$, J Yagüe ${ }^{3}$ \\ From 8th International Congress of Familial Mediterranean Fever and Systemic Autoinflammatory Diseases \\ Dresden, Germany. 30 September - 3 October 2015
}

Clinical picture of CAPS syndrome includes periodic fever, skin rash, arthritis / arthralgias, conjuntivitis, and neurisensorial deafness with hereditary pattern and early onset ( $<1 y$ in $50 \%$ of cases). In last decade, atypical manifestations have emerged expanding the clinical spectrum of CAPS.

\section{Question}

To evaluate the clinical, laboratory and genetic profile of 26 patients of 4 spanish unrelated pedigrees with special attention to the atypical manifestations of the disease.

\section{Methods}

Review of clinical, analytical and genetical data of a cohort of 26 patients from 4 unrelated non-consanguineous Spanish pedigrees.

\section{Results}

Rash (14/26), arthritis (14/26), and deafness (12/26) were the most common features. Episodic fever accounted in $8 / 26$ patients. $14 / 26$ patients did not present episodic course and disease onset was over 10 years in $17 / 26$ patients. 2/26 patients developed amyloidotic hemorrhagic cystitis and other $2 / 26$ patients explained olfactive disfunction. Amyloidosis was confirmed in $2 / 26$ patients and considered as probable in other $4 / 26$ patients. Acute phase reactants were normal in $7 / 26$ patients. CIAS1 mutations were identified in $23 / 26$ patients (Ala439Thr in 5, Arg488Lys in 6 and Arg260Trp in 12). 5/6 patients carriers of an heterozigous Arg488Lys mutation were asymptomatic while it failed to isolate any CIAS1 germinal, somatic or mosaic mutation in 3 members of the same pedigree although their clinical profiles were consistent with Muckle-Wells syndrome (1 case) and CINCA / NOMID (2 cases).

${ }^{1}$ Hospital Vall D'Hebron, Internal Medicine, Barcelona, Spain

Full list of author information is available at the end of the article

\section{Conclusions}

Despite the traditional clinical picture of CAPS includes periodic fever, rash, arthritis and deafness with onset usually $<1$ year, in its absence CAPS cannot be ruled out. The clinical spectre may vary from the chronic afebrile course, to atypical amyloidosis, or olfactive disfunction. The profile of CIAS1 mutations carriers may include asymptomatic individuals or absence of mutations in pedigrees with several members with a highly suggestive clinical profile of severe variants of CAPS syndrome.

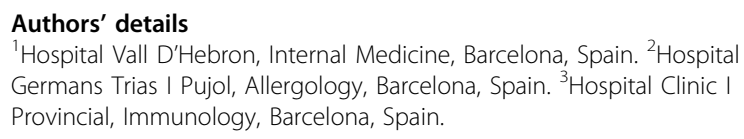

Published: 28 September 2015

doi:10.1186/1546-0096-13-S1-P66

Cite this article as: Buján-Rivas et al:: Atypical manifestations in CAPS sydrome: not so unfrequent? Pediatric Rheumatology 2015 13(Suppl 1): P66.

Submit your next manuscript to BioMed Central and take full advantage of:

- Convenient online submission

- Thorough peer review

- No space constraints or color figure charges

- Immediate publication on acceptance

- Inclusion in PubMed, CAS, Scopus and Google Scholar

- Research which is freely available for redistribution
C Biomed Central

(C) 2015 Rivas et al. This is an Open Access article distributed under the terms of the Creative Commons Attribution License (http:// creativecommons.org/licenses/by/4.0), which permits unrestricted use, distribution, and reproduction in any medium, provided the original work is properly cited. The Creative Commons Public Domain Dedication waiver (http://creativecommons.org/publicdomain/ zero/1.0/) applies to the data made available in this article, unless otherwise stated. 